\title{
THE USE OF GRAMMAR-TRANSLATION METHOD TO TEACH READING TO THE TENTH CLASS STUDENTS AT SMK YPM 12 TUBAN ACADEMIC YEAR 2020/2021
}

\author{
Ali Fauzi \\ Program Studi Pendidikan Agama Islam, Institut Agama Islam Nahdlatul Ulama \\ (IAINU) Tuban \\ Email: alifauzi@ stitmatuban.ac.id
}

\begin{abstract}
English is the first foreign language in Indonesia which is considered important in transferring and developing science and technology, arts and building the relationship among countries. Based on the 1994 basic course outline, the purpose of English teaching at Technical Senior High Schools is to develop the four language skills: listening, speaking, reading and writing. The teaching of those four language skills can be done in integrative way in which the emphasis is on developing the students' reading skill. The less attention to a certain language skill may cause the students' unbalanced mastery of English. However, teaching reading using certain method like grammartranslation method is also important because by it students will be able to understand the English text, grammar and structure and translation well through which they will be a means of improving other skills such as speaking. From the reasons, the researcher wants to study about The Use of Grammar-Translation Method to Teach reading to the Tenth Class Students at SMK YPM 12 Tuban Academic Year 2020/2021. This title is chosen because he is sure that reading is also important besides speaking, writing and listening.

This study is in form of descriptive analysis which means that he describes what he finds in the real life and he reveals them to prove the rightness of his assumption. He tries to find the data and process them and just describes his finding. He analyzes and describes about the use of grammar-translation method in teaching reading and the problems the teacher and students face in the process of teaching and learning. Besides them, it is also prominent to tell the process or activities in the teaching of reading using grammar-translation method. It is hoped that some alternatives to solve these problems can be found. Therefore it is expected that this study will be useful for English teacher as the alternative method to teach reading, for the readers to add their knowledge about different ways in teaching reading and for the students in general to be the reference to add their knowledge and to do further research.
\end{abstract}

Key Words: Grammar-Translation Method, Teaching, Reading, Students, SMK YPM 12 Tuban

\section{INTRODUCTION}

Language is a means to convey ideas, feelings, and thoughts. English is the first foreign language in Indonesia which is being considered important in transferring and developing science, technology, arts, and building the relationship among countries. Considering the importance of English as a means of communication as well as a way to master science and technology, the Indonesian government gives it a special position in the SMK Curriculum. It is proved by the fact that English becomes a compulsory subject in secondary schools. Based on the 1994 English Basic Course Outline, the purpose of English teaching at Technical Senior High Schools is to develop the 
four language skills: listening, speaking, reading and writing which stresses on the ability of understanding the language used in technical school. The teaching of those four language skills is based on students' interests and their mastery of vocabulary and grammar. The four language skills are taught in integrated way in which the emphasis is on developing the students' reading skill generally English language and especially the technical language (Depdikbud RI, 1994:1). In relation to the demand above, the English teachers at Technical Senior High Schools focus on the English teaching more upon passage or comprehension and the vocabulary mastery on technical language. The less attention to a certain language skill results in the students' unbalanced mastery of English. One of the skills the teacher teaches to the students is reading. However, the English teacher must also find the way to teach reading to them because it is very important for them to be able to understand English text, to understand grammar and structure and to develop vocabulary as well as to know the meaning of the whole words correctly. If the teacher does not stress on teaching of reading, the understanding of English of students do not develop well.

The policy which emphasizes on teaching reading skill seems to give adequate reading skill to the students who want to continue their study at universities and to get a job since they will have to read many English textbooks and to get English communication in the job interview. Nevertheless, the teacher should not ignore the other skills since not all of the high school graduates will continue their study in universities for some reasons. Some of them may want to work which speaking skill become plus point for them. To be able to speak well, they must have enough vocabulary and to have the vocabulary, they need read much. There are some methods which can be used to teach reading skill, and one of them is grammar-translation method. Grammar-Translation Method (GTM) is a method usually used in learning foreign language including English. It is a learning method which teaches students Grammar and the language regulation and construct the words to become good structure and translate them into first language. Therefore, it is said that Grammar-Translation Method is an English learning method which focuses on the grammar, and structure and translation. In short, GTM is a combination method of grammar and translation. In thid method, the students are not only asked to be able to translate but to understand the grammar and structure well. The impact of understanding grammar, structure and knowing the meaning of whole sentences will of course increase the number of vocabulary and the ability of speaking.

GTM was firstly known in 1840 and used to learn Latin and Greek Languages and it is not something new. In the old time, this method was often called "Classical Method" because it was often used to learn classical Latin and Greek languages. Teachers often used GTM because it enabled them to deliver the subject and the students were easier to understand the materials of learning. GTM method is often used today either at Junior High School or Senior High School. The 
teachers often translate English into Indonesian and explain grammar and structure comprehensively. In this method, students read, learn and analyze based on the grammar and structure of the English text and then they translate it. It is sure that this method has strength and weaknesses. The strength is (1) it can develop the skill of students to read, to write and to trans late English text (2) It enables students to learn English because they may use Indonesian during the process of learning (3) it forms strong memory of the students because they usually relate the English words in their memory (4) it is easy to apply this method and does not need special skill. The weaknesses of this method is (1) it focuses on the skill of reading and writing but does not touch on the skills of listening and speaking, (2) it is only appropriate to the smart students (3) it makes students think hard because they must think double languages, (4), it makes teachers lazy because it does not need good teaching preparation, and the impact is that their English do not improve. Nevertheless, many experts think that Grammar-Translation Method is the most effective method to understand English because (1) it enables teacher to explain the English material fast, (2) teacher and students are easy to communicate both in English or Indonesian, (3) Students are easier to understand the regulation of the method because it has been translated and they just focus on the translation and grammar. However, this method is considered boring, conventional, and out of date. In fact whatever the method used, to get the English achievement, it depends on the skill and the creativity of the teacher, the technique and media of learning, and the skill of class management.

In teaching reading, the teachers have very important role because they are the key figures in the language learning and they have to be able to set for the learning activities. The creativity of the teacher will play a big role in the teaching-learning process. To increase the reading ability of Senior High School students, an English teacher should find and create various activities and implementation on those activities in their class. The teacher should be wise in making decisions of selecting teaching activities, students' learning activities and instructional material, media and method that will enable the largest possible number of students to gain the objectives at an acceptable level of achievement in a reasonable amount of time (Kemp, 1977: 56). The teacher also needs to know the strengths and weaknesses of alternative method, techniques, media and of various materials to be selected based on students' characteristics and needs.

In accordance with the implementation of 1994 Curriculum that adapts the Communicative Approach, nowadays English teaching in senior high school is focused not only on developing the grammatical competence, but also on developing the communicative competence. The students are not only taught about the structure, sounds, or words of the language, but a lso know how to use language for different purposes. In the communicative approach, communicative competence is the desired goal, i.e. the ability to use the linguistic system effectively and 
appropriately (Finocchiaro and Brumfit, 1983: 92). Further, Littlewood (1984: 1) states that the Communicative Language Teaching means little more than in integration of grammatical and functional teaching. He says that one of the most characteristic features of Communicative Language Teaching is that it pays systematic attention functional as well as structural aspects of language. Through CLT, the teachers can give communicative activities which will enable the students to practice their English. Those activities should focus on the students' interest and needs so that they can improve their knowledge and skills in real communication. Closely related to the selection of teacher and student activities, it is necessary for language teachers to be familiar with method and media to support the learning- teaching process. In many instructional situations today, method and media are no longer supplementary to instruction, but they also provide the main instructional input (Kemp. 1977:73). He further states that method and media can motivate the students and can effectively explain and illustrate subject content. It can be more efficient for the students to see a place, a function, or a relationship than just to hear or read. However, we have to remember that communicative goal can be gain by learning reading using grammar-translation method.

To this day, many English teachers use method to teach English especially reading. The use of method plays an important part to help the teachers to increase the classroom interactions which enables to gradually develop students' reading ability. Therefore, the main function of instructional method is to support the teaching method used by the teachers. It is hope that the use of instructional method can improve the quality of the teaching-learning process which can ultimately influence the quality of students' learning outcome. There are many kinds of methods which are used to support the achievement of learning objectives and one of them is grammartranslation method. To limit the discussion, this study will only discuss grammar-translation method which can be used as a method in classroom activities. It looks that the use of Grammar-translation method in teaching reading to the tenth class A students of machine technics at SMK YPM 12 Tuban is quite helpful in developing their English reading skill.

Before discussing about teaching reading, it is better to know the meaning of reading itself. Hornby (1974: 698) says that reading is an activity in which one makes use of language to understand the text. Furthermore, Hornby states that grammar is a science of rule for, the combination of words into sentences and translation (noun) is giving the meaning of any written language in another language. So grammar-translation method is the combination method of grammar and translation (1974: 919). The researcher is sure that students also need the skill of reading and wants to prove that reading can be taught to the students through the method of Grammar-translation. Therefore he chooses the title of the research "The Use of Grammar- 
Translation Method to Teach Reading to the Tenth Class Students at SMK YPM 12 Tuban Academic Year 2020/2021."

\section{METHODOLOGY}

The approach of this study is phenomenological approach in which the researcher tries to find and to interpret the facts and the causes of things based on the phenomena in the classroom and the researcher's view although it may be subjective (Arifin, 1994: 46-47). On account of the fact that the researcher uses phenomenological approach and he must interpret phenomena in the classroom, so he uses hermeneutic - a method in understanding and in interpreting phenomena - in the discussion and the description of data (Ratna, 2004: 44-45). It means that the researcher tries to observe the use of grammar-translation method in teaching reading to the students based on his own interpretation. In the research, the researcher functions as the main instrument, he describes the data, stresses on the process more than the result, focuses on the main points, discusses the research finding and describes all finding in a such way (Moleong, 2017 4-8). This study is qualitative research in form of library research. It means the researcher explains the use of grammar-translation method and describes the implementation of the method in teaching reading the classroom. The researcher describes the data in three phases. The first is data reduction- the process of selecting, focusing and transforming data supporting the description. The second is data descriptiondescribing all finding data he uses in the teaching of reading using grammar-translation method. The third is data conclusion - concluding the discussion (Miles and Huberman, 1984: 48-51). He also finds data from many literatures to get theory and principle as the secondary data used as a means to explain the use of grammar-translation method (Suharsimi Arikunto, 2002:23). The researcher uses descriptive-qualitative method. It means that he just describes his research finding about the use of grammar-translation method in teaching reading to the students. The method of analysis describes phenomena in the classroom during the process of teaching and learning through collecting data, analyzing data and interpreting data so that the research will be valid and reliable (Surahmad, 1972: 131).

The object of the research is the students of tenth class A Teknik Permesinan of SMK YPM 12 Tuban academic year 2020/2021. The number of students is 41 as it is stated below: 
THE LIST OF STUDENTS CLASS X A TEKNIK PERMESINAN

SMK YPM 12 TUBAN

ACADEMIC YEAR 2020/2021

\begin{tabular}{|c|c|c|c|}
\hline NO. & $\begin{array}{c}\text { NATIONAL } \\
\text { NUMBER (NISN) }\end{array}$ & NAME & $\mathbf{M} / \mathbf{F}$ \\
\hline 1 & 0048404912 & ABDUL MUHAMMAD FAJAR MAFUD TRIONO & $\bar{M}$ \\
\hline 2 & 0045460886 & ACHMAD IMRON MUJIB & $\bar{M}$ \\
\hline 3 & 0049165730 & ACHMAD SETYA FARNADI & $\bar{M}$ \\
\hline 4 & 0039156175 & AHMAD FERI FATKURROZI & $\mathrm{M}$ \\
\hline 5 & 0042329683 & AHMAD LATIF NURIYONO & $\bar{M}$ \\
\hline 6 & 0038731885 & AHMAD YASIN & $\mathrm{M}$ \\
\hline 7 & 0049841096 & AHMAD ZAKI AMIRUDIN & $\bar{M}$ \\
\hline 8 & 0037045239 & AHMAT PUTRA ANOM & $\mathrm{M}$ \\
\hline 9 & 0049459354 & ALDI BAGUS SAPUTRA & $\mathrm{M}$ \\
\hline 10 & & ANDIKA WIYANTO & $\mathrm{M}$ \\
\hline 11 & 0049936387 & ANDRI EKA PRASETYO & $\bar{M}$ \\
\hline 12 & 0042742451 & ANDRI GOVINDA PURBA KRISNA & $\mathrm{M}$ \\
\hline 13 & 0035721006 & ARDIAN DAVI PRATAMA & $\mathrm{M}$ \\
\hline 14 & 0072295445 & ARI JULIANTO & $\mathrm{M}$ \\
\hline 15 & 0051943892 & BAGUS ADI PANGESTU & $\mathrm{M}$ \\
\hline 16 & 0042844047 & CAHYO MUHAMMAD HAJAD & $\bar{M}$ \\
\hline 17 & 0047818649 & CANDRA DWI DUMADI & $\bar{M}$ \\
\hline 18 & 004434876 & DAFIT REFANGGA & $\bar{M}$ \\
\hline 19 & 0043826741 & DAVID KURNIA AFANDI & $\mathrm{M}$ \\
\hline 20 & 0049616907 & DENISA VIRGIANI PRATAMA & $\mathrm{M}$ \\
\hline 21 & 0057302330 & DARMA RIDHO ALFAN & $\bar{M}$ \\
\hline 22 & 0043402072 & DICKY ADRIAN WINATA & $\mathrm{M}$ \\
\hline 23 & 004399508 & DICKY MAULANA & $\mathrm{M}$ \\
\hline 24 & 0047871291 & DIKI RIONAL & $\mathrm{M}$ \\
\hline 25 & 0043181668 & DION PRANATA & $\mathrm{M}$ \\
\hline 26 & 0048773051 & DODIK RIYANTO & $\mathrm{M}$ \\
\hline 27 & 0046238012 & ERLANGGA & $\mathrm{M}$ \\
\hline 28 & 0044480961 & FEBRARY AGENG SELOWA & $\mathrm{M}$ \\
\hline 29 & 0054180905 & FEBRI RISKI ARIYANTO & $\mathrm{M}$ \\
\hline 30 & 0055635228 & HAMDAN ROMADHON & $\mathrm{M}$ \\
\hline 31 & 0048711141 & HANDIKA ARIEF DANIEL & $\bar{M}$ \\
\hline 32 & & HENDRIK SUSANTO & $\mathrm{M}$ \\
\hline 33 & 0038940241 & NURHADI UTOMO & $\mathrm{M}$ \\
\hline 34 & 0047766104 & JUWANTO & $\bar{M}$ \\
\hline 35 & 0059868734 & KHOLID IFFAN ANDIKA & $\mathrm{M}$ \\
\hline 36 & 0037426979 & M. BUDIYONO SAPUTRO & $\mathrm{M}$ \\
\hline 37 & 0049701656 & M. DHEVIT & $\mathrm{M}$ \\
\hline 38 & 0048611919 & MOKHAMMAD VIRGI AINUL YAQIN & $\mathrm{M}$ \\
\hline 39 & 0046418148 & MOHAMMAD HARIS RAMADLANI & $\bar{M}$ \\
\hline 40 & 0048343364 & M.HUDAN NAFIRLY & $\mathrm{M}$ \\
\hline 41 & 0036910983 & MOCHAMAD ANGGA LISTIYA WAHYUDI & $\mathrm{M}$ \\
\hline
\end{tabular}

Tadris, Volume 15/No. 1/Tahun 2021 |29 


\section{DISCUSSION}

\section{The Use of Grammar-Translation Method to Teach Reading to the Tenth Class Students}

at SMK YPM 12 Tuban.

a. In this study, the researcher only uses one class that is the students of the tenth class A Teknik Permesinan which consists of 41 students. The steps of teaching reading using grammar-translation method is as follows:

\section{a. Pre-Activity}

In this first phase, the teacher greets students saying "Assalamu'alaikum", "Good morning everybody", and the students answer, "Waalaikum salam," "we are fine, thank you, and you?". "I am pretty well”, the teacher answers. The teacher then opens the meeting and introduces the subject which they are going to discuss in the meeting. He then (1) gives a short passage or long passage to the students, (2) asks students to read them by heart, and (3) asks students to think the answer of the questions. The examples of the passages are seen below:

b. Read the Passages and Answer the questions below:

\section{An Exciting Trip}

I have just received a letter from my brother, Tim. He is in Australia. He has been there for six months. Tim is an engineer. He is working for a big firm and he has already visited a great number of different places in Australia. He has just bought an Australian car and has gone to Alice Springs, a small town in the center of Australia. He will soon visit Darwin. From there, he will fly to Perth. My brother has never been abroad before, so he is finding this trip very exciting.

1) What has the writer just received from his brother, Tim?

2) Is Tim an engineer, or is he a doctor?

3) How long has he been in Australia?

4) Has he already visited many places or not?

5) Where is he now?

6) Has Tim ever been abroad before or not?

7) Is he enjoying his trip very much or not

\section{The Advantages of Much Reading}

When we entered the elementary school, the teacher taught us reading. After six years of studying, we can read very easily. The enjoyment of reading must be renovated seriously. How can we establish that enjoyment? There are many ways to build the hobby of reading. Founding libraries is one of the answers. Printing all kinds of cheap books is another way to 
establish the reading interest. Newspapers that reach the villages are important means to create reading habit. The government has been working hard to wipe out the illiteracy. The illiteracy is an obstruction of development.

Why should we read much?. There are many advantages of reading. Books are good teachers. By reading we enlarge our knowled ge of everything. We can absorb the knowledge of the developed countries. We can compare their knowledge with ours. If we feel ours is lower, we can study from them. From the newspapers people know that American astronauts have landed on the moon. Some books tell us the way to produce much rice and other crops in small land. The use of fertilizers, good irrigation system and good seed are found in the agricultural books. Geography books explain the way to prevent floods in the wet season. They also tell us the danger of blindly wood cutting. The woods may be bare, the earth is not able to hold the rain, and the floods cannot be prevented.

Other books inform us how to cure many kinds of diseases. The discoveries of new medicines help us live healthily. The Ministry of Health explains the advantages of the family planning. Having only two children could make people live happier. Books about sports can be found easily. Those books tell us how to practice many kinds of sports correctly. Reading always gives us a lot of advantages.

1) Why should the enjoyment of reading be renovated?

2) How can we establish the hobby of reading?

3) What is the function of a library?

4) The illiteracy is an obstruction of development. Given a short explanation.

5) How can cheap books establish the reading interest?

6) There are many advantages of reading. Give some examples!

7) What may we have by reading?

8) How do people know that American astronauts have landed on the moon?

9) What do geography books explain?

10) What do books of sports tell us?

\section{b. Activity}

In this phase, the teacher may use the media of learning like LCD and the like and must do as follows:

(1) The teacher asks students to read loudly. He may ask students to read one by one or take the part of them in random. When the students read falsely or find difficulty in reading the passages either in spelling or pronunciation, he must evaluate and show them until they are really able to read correctly. 
(2) The teacher explains students the grammar and structure used in the passages. He invites students to analyze the passages to find grammar and structure used. For example, "let's see the first passage entitle "an Exciting Trip." "You know that the passage uses present tense in form of simple present tense, present perfect tense, present future tense, present continuous tense and the to be used is also present." The teacher then ask the students, "do you know what is simple present tense?, what is present perfect tense? What is present future tense, what is present continuous tense? and what to be do you find?." The teacher then explains the tenses shortly and take the example from the passage.

(3) The teacher must also do the step for the second passage entitle The Advantage of Much Reading. He must explain the grammar and structure used in the passage as it is done in the first passage. For example, "let's see the second passage entitle The Advantage of Much Reading. "You know that the passage uses tense in form of simple past tense, simple present tense, present perfect tense, present perfect continuous tense, present future tense, present continuous tense, the use of to be, noun (singular and plural), verb modal, auxiliary verb, active and passive voice, adverb and degrees of comparison.” The teacher asks the students the grammar and the structure used in the text wholly. The teacher then explains the grammar and show the structure shortly and take the example from the passage. In the end, he must be sure that the students understand the subject they discuss.

(4) The teacher asks students to translate the passage. He may ask them to translate into Indonesian one by one and if the students find difficulty in translating them, he must show them the correct one.

(5) The teacher asks the students to answer the questions. Before he asks them to answer the question, he must explain how to answer the questions correctly.

(6) The teacher gives homework to the students.

(7) The teacher gives opportunity to the students to answer the questions if they do not understand the material given.

\section{c. Post-Activity}

In this phase, the teacher closes the meeting by saying parting to the students. He may say "Let's close our meeting by saying Alhamdulillah and see you next week." The students answer, "Alhamdulillah, see you next sir." "Thank you very much for the nice meeting."

\section{The Problem of Using Grammar-Translation Method in Teaching Reading}

Reading is an important part for people in mastering a language. A language is not only used in spoken or oral form but also in written forms. A person who studies a language must pay the 
whole attention which includes reading, writing, speaking and listening so that he is able to use language in his daily life in balance. Grammar-translation method is an old method and considered conventional method, so today this method is rarely used. However, this method is still said to be the most effective method to teach English because in one meeting they will study many things like grammar, structure, translation besides reading itself. Like other ways in using teaching method, there are some problems in teaching reading using grammar-translation method. If we find the problems of teaching reading using grammar - translation method and we can solve the problems well, so we will be able to find good result from teaching-learning process. In this study the researcher wants to analyze about the problems faced by the teacher, the student and the school in the use of grammar-translation method to teach reading to the tenth class students of Technical Senior High School SMK YPM 12 Tuban.

\section{a. Problems Faced by the Teacher}

A teacher has the big role in teaching-learning process. He has duty to increase the quality of the students. Dealing with the teaching reading using grammar-translation method to the tenth class students of Technical Senior High School SMK YPM 12 Tuban, the researcher finds some problems faced by the teacher. The first problem is the difficulty to find good books which are relevant with the teaching reading using grammar-translation method. Grammar-translation method is an old method which is rarely used today. Therefore, the information about this method is not enough to equip teacher to master the method. To solve this problem the teacher tries to find through all ways and must be creative to adapt the situation in the classroom with the method. The second problem is that before teaching, the teacher must prepare many things well because it needs well-preparation; they must be able to explain the way of reading, the grammar and structure and to translate the material well. To solve the problem, the teacher has to prepare it well; he must be ready to anticipate all problems during teaching-learning process. The third problem is that this method is boring. To solve the problem, the teacher must be able to create the situation of teaching-learning process enjoyable. He must be creative to apply media and technique of teaching which enable students enjoy the situation. The fourth problem is that it needs long time to finish the materials because too many things to cover. To solve the problem, besides the teacher must be able to manage the time, the teacher must limit the discussion on certain topic. If the time of meeting is not still enough, the teacher can finish it in the next meeting. 


\section{b. Problems Faced by the Students}

Students are the main objects in teaching-learning process. There is also the important item that influences the output or result or the teaching and learning process. Their motivation and creativities become the key to be successful in learning English. Pleasant condition is needed to support the student's activities. There are some problems faced by the tenth class of Permesinan department students at Technical Senior High School SMK YPM 12 Tuban in teaching reading using grammar-translation method. The first problem is that this method is boring. To solve the problem, the students must have strong intention to learn English reading. They must realize that to get knowledge is not easy and it needs struggle. The second problem is that in grammar-translation method, the students must think many items. They must think the English spelling, pronunciation, grammar and structure and translation. It is hard burden for them. To solve this problem, they must learn how to read the passage and discuss the grammar and structure and translate them in relax. The third problem is that they think that reading is less important than speaking. They think speaking is needed in their profession next. To solve this problem, they must realize that it is impossible for them to be able to speak well if they do not have enough vocab, grammar and structure skill and know the meaning of the words well. If the subject of reading taught using grammartranslation method, they automatically will learn the skills needed to be able to speak English.

\section{CONCLUSION}

As we know that the success of teaching and learning process is determined by many factors. One of them is the method used by the teacher. In teaching language, especially reading which is a foreign language for Indonesians, a teacher is demanded to be well-prepared and creative in planning and carrying out activities. By applying various techniques and exciting media, the teacher will be able to maintain and develop students' motivation and interest. Therefore, something to arouse students' motivation and to increase their interest is needed. Teacher may use grammartranslation method to help them to achieve his teaching objectives. He considers that this method is effective to gain the objective of teaching and learning because in one time of meeting, they learn many things - reading, grammar and structure and translation although this method is boring. In relation to the use of grammar-translation method in the reading class, it really stimulates students to understand many things in one time. Even, they provide an opportunity to practice other language skills like speaking, writing and listening. By using this method, students do not realize that they have equipped themselves with the skill of reading, grammar, structure and translation which enable 
them to be ready to do their professions after they graduates from the school. It is right that using grammar-translation method in teaching reading has many problems but if we intend to learn English seriously, it can be solved. The main key to learn English is that we must learn diligently because without it we will not be able to master English.

\section{REFERENCES}

Alexander, LG. 1967. Practice and Progress. London: Longman group limited.

Arifin, Imron (ed). 1994. Penelitian Kualitatif dalam Ilmu-ilmu Sosial dan Keagamaan. Malang: Kalimasada Press.

Arikunto, Suharsini. 2002. Prosedur Penelitian Suatu Pendekatan Praktek. Jakarta: Rineka Cipta.

Brown, James W., Lewis, Richard B and Harcleroad, Fred F. 1983. An Instruction Technology, Media and Method. USA : MAC. Grow-Hill,inc.

Depdikbud.1994. Kurikulum Sekolah Menengah Umum. Jakarta : Depdikbud.

Hornby, A.S. 1974. Oxford Advanced Learner's Dictionary of Current English. London: Oxford University Press.

Kemp, Jerrold E.1977. Instructional Design. California : David S. Lake Publishers.

Littlewood, W. (1984). Communicative Language Teaching. USA : CUP.

Miles, Matthew B \& Michael Huberman. 1984. Analisi Data Kualitatif Bahasa; Tjejep Rohendi Rohidi. Jakarta: Universitas Indonesia.

Moleong, J. Lexy. 2017. Metodologi Penelitian Kualitatif. Bandung: PT. Remaja Rosdakarya.

Ratna, Nyoman Kutha. 2004. Teori, Metode, dan Teknik Penelitian Sastra. Yogyakarta: Pustaka Pelajar.

Surachmad, Winarno. 1972. Pengantar Penelitian Ilmiah Dasar. Bandung: Tarsito.

Yahya, Iskandar et al. 1987. Structure and Reading Comprehension. Bandung: PT. Orba Shakti. 